\title{
Constipation: an overlooked, unmanaged symptom of patients with pheochromocytoma and sympathetic paraganglioma
}

\author{
Sonali Thosani ${ }^{1}$, Montserrat Ayala-Ramirez ${ }^{1}$, Alejandro Román-González ${ }^{1,2}$, \\ Shouhao Zhou ${ }^{3}$, Nirav Thosani ${ }^{4}$, Annette Bisanz ${ }^{5}$ and Camilo Jimenez ${ }^{1}$ \\ ${ }^{1}$ Department of Endocrine Neoplasia and Hormonal Disorders, The University of Texas MD Anderson Cancer Center, \\ 1400 Pressler Street, Unit 1461, Houston, Texas 77030, USA, ${ }^{2}$ Department of Endocrinology, Hospital San Vicente \\ Fundacion-Universidad de Antioquia, Medellin, Colombia, ${ }^{3}$ Department of Biostatistics, The University of Texas MD \\ Anderson Cancer Center, Houston, Texas, USA, ${ }^{4}$ Department of Gastroenterology, Hepatology and Nutrition, \\ The University of Texas Health Science Center at Houston, Houston, Texas, USA and ${ }^{5}$ Independent Nurse Consultant, \\ retired from The University of Texas MD Anderson Cancer Center, Houston, Texas, USA
}

Correspondence
should be addressed
to C Jimenez
Email
cjimenez@mdanderson.org

\begin{abstract}
Objective: Pheochromocytomas (PHs) and sympathetic paragangliomas (PGs) are tumors that produce catecholamines, predisposing patients to cardiovascular disease and gastrointestinal effects such as constipation. Objectives: i) determine the prevalence of constipation, its risk factors, and its impact on survival; ii) identify whether a systematic combination of fiber, water, and laxatives was effective for treatment of constipation.
\end{abstract}

Design and methods: We retrospectively studied 396 patients with PH/PG diagnosed in 2005-2014. The study population was patients with constipation as a presenting symptom; the control group was patients without constipation as a presenting symptom. The MD Anderson Symptom Inventory was used to assess constipation and quality of life.

Results: Twenty-three patients $(6 \%)$ had constipation. Constipation was associated with headaches, palpitations, diaphoresis, weight loss, and excessive noradrenaline production $(P<0.0001)$. Eighteen of these patients had non-metastatic primary tumors larger than $5 \mathrm{~cm}$ and/or extensive metastases. No statistically significant differences in age, sex, and genotype were noted between the study and control groups. In patients without metastases, resection of the primary tumor led to symptom disappearance. A systematic combination of fiber, water, and laxatives was associated with symptom improvement.

Two patients who presented unmanaged constipation died because of sepsis from toxic megacolon.

Conclusions: Constipation is a rare and potentially lethal complication in patients with PH/PGs. Severe constipation can be prevented by recognizing and treating mild symptoms.

\section{Introduction}

Pheochromocytomas (PHs) and sympathetic paragangliomas (PGs) are rare neuroendocrine tumors. These tumors' hormonal secretions have systemic effects. The most well-recognized and characterized systemic manifestation of $\mathrm{PH} / \mathrm{PG}$ is cardiovascular disease, such as uncontrolled hypertension and tachycardia, which often lead to the initial suspicion of the diagnosis. While these effects are usually aggressively addressed, other manifestations involving other body systems are often overlooked. Among these, gastrointestinal manifestations may account for significant morbidity and mortality. Indeed, there are several case reports of PH/PG patients who have had severe constipation that resulted in paralytic ileus, bowel ischemia, gastrointestinal bleeding, and even colonic perforation $(1,2,3,4,5)$. None of these reports have characterized this set of

Published by Bioscientifica Ltd. 
complications, nor did they provide clear guidance on their prevention and treatment.

The purpose of this study was to identify the prevalence of constipation in patients with $\mathrm{PH} / \mathrm{PG}$, the risk factors associated with constipation, its impact on survival, and insights on diagnosis, monitoring, and treatment of this condition. We report the results of a retrospective study of $\mathrm{PH} / \mathrm{PG}$ patients treated at our institution, a tertiary referral center.

\section{Patients and Methods}

\section{Definitions}

Constipation was defined as: i) unsatisfactory defecation characterized by infrequent bowel movement $(<3$ bowel movements/week); and/or ii) difficult stool passage that includes straining, a sense of incomplete evacuation, hard/lumpy stool, prolonged time to defecate or pass stool, or need for manual maneuvers to pass stool. Patients with symptoms lasting longer than 3 months were categorized as having chronic constipation on the basis of the American Gastroenterological Association criteria for chronic constipation (6). For the purpose of this study, we assessed the severity of constipation using the Common Terminology Criteria for Adverse Events version 4.0 (CTCAE 4.0), as follows: grade 1: occasional or intermittent symptoms; occasional use of stool softeners, laxatives, dietary modification, or enemas; grade 2: persistent symptoms with regular use of laxatives or enemas; symptoms limit instrumental activities of daily living (driving, seating); grade 3: manual evacuation is indicated; symptoms limit self-care activities of daily living; grade 4 : life-threatening consequences; urgent intervention indicated; grade 5: death resulting from the constipation.

\section{Data collection}

After obtaining approval from the MD Anderson Cancer Center institutional review board, we searched the MD Anderson tumor registry for patients diagnosed with PH/PG between January 2005 and August 2014. Of the 412 patients identified, 396 met our inclusion criteria of having radiographic and histopathologic information available and having undergone treatment and follow-up at MD Anderson. We created a database of these patients using Microsoft SQL Server (version 2008; Microsoft Corporation) and Microsoft Office (version 2007; Microsoft Corporation). We captured 156 variables including demographic, clinical, laboratory, imaging, pathology, and treatment information. Primary tumor location and size and, in the case of malignancy, metastases were verified by pathologic, surgical, and radiographic reports. In most patients, the size of the primary tumor was determined by pathology report. In patients in whom the primary tumor was not removed, the size was determined by radiographic measurements. Abdominal series and CT/MRI scans of the abdomen and pelvis were evaluated for signs of constipation and complications. We reviewed the medical charts for details about medical history and symptoms at initial presentation and at follow-ups. Data were also taken from the database of the patients' history forms, the MD Anderson Symptom Inventory form they had filled out prior to every clinic visit; this form, used at MD Anderson since 2000, asks patients about chief complaint and a detailed review of systems that includes questions about the characteristics of gastrointestinal symptoms such as constipation (7). When there was a discrepancy between the patient history form and the dictated clinic note from that visit, a positive symptom reported in either document resulted in the patient being included in the study.

In patients with constipation we documented the presence of clinical sequelae of chronic constipation, such as hemorrhoids, anal fissures, fecal impaction, stercoral ulcers, and bleeding. Because the presence of hard stools compounded with infrequent bowel movements can cause colonic dilatation, we searched for clinical or radiographic evidence of diverticulosis, megacolon, or volvulus. Because the increase in colonic size can compress surrounding nerves, which contributes to poor motility and pelvic floor disorders, such as vesico-ureteral reflux (especially in women), we also searched for evidence of urinary tract infections and urinary incontinence (8).

\section{Therapeutic interventions}

The medications listed in patients' records were reviewed and classified as $\alpha$ - and $\beta$-blockers, tyrosine hydroxylase inhibitors, laxatives, and/or medications that could cause constipation. Laxatives were subclassified as stimulant laxatives that induce peristalsis (e.g., senna, bisacodyl (Dulcolax; Boehringer Ingelheim Pharmaceuticals, Ridgefield, CT, USA), cascara), osmotic laxatives that increase fluid volume in the bowel (e.g., magnesium hydroxide, polyethylene glycol (MiraLAX; Bayer Corporation, Pittsburgh, PA, USA)), stool softeners that help hold fluid in stool (e.g., docusate sodium (Colace; Purdue Products, Stamford, CT, USA)), and lubricants (e.g., mineral oil) (9).

After presentation, all $\mathrm{PH} / \mathrm{PG}$ patients with constipation underwent medical interventions following the 
algorithm presented in Fig. 1. This algorithm, based on expert opinion and extensive literature review, was developed by Annette Bisanz, RN, at MD Anderson for the treatment of constipation in patients with cancer $(10,11)$. The following tenets apply to this algorithm: i) Patients with severe constipation must be initially treated with lubricants and osmotic laxatives until frequent bowel movements are obtained. Lubricants and osmotic laxatives soften the stool and add fluid, making the intestinal transit faster and more comfortable and stool elimination easier. ii) Stimulant laxatives and stool softeners should not be used initially for the treatment of grade 3 and 4 constipation; stimulants can cause serious cramping (12), because these patients have large amounts

\section{A. Acute intervention for grade 3 and 4 constipation:}

1. Assess the consistency of the patient's last bowel movement. If the last bowel movement was very hard, the patient should drink two tablespoons of mineral oil three times daily unless he or she is on aspiration precautions.

2. The patient should drink a bottle of magnesium citrate over ice over a period of 30 min daily for 2 consecutive days. Magnesium citrate should not be taken after $1600 \mathrm{~h}$ so as to avoid interfering with sleep at night. Magnesium citrate tastes better cold than at room temperature. For patients with renal failure, use lactulose $30 \mathrm{cc}$ twice daily instead of magnesium citrate.

3. The patient should drink eight ounces of water every hour.

4. Start milk and molasses enemas* 4 times daily (as close as $2 \mathrm{~h}$ apart) until the entire formed stool is eliminated and the stool turns to liquid.

5. Do not use tap-water or normal-saline enemas. Patients cannot hold large volumes when the colon is full of stool.

6. The patient should drink warm liquids (e.g. tea, coffee, milk) four to six times daily as tolerated. Warm and hot beverages increase intestinal motility

7. Start intravenous normal saline in patients with elevated creatinine levels. Patients may be dehydrated because of nausea, vomiting, and lack of water intake.

8. If constipation is unresponsive to previous measures, consider polyethylene glycol 3350/electrolyte solution (Golytely).

*Recipe: $3 / 4$ cup of water, three ounces of powdered milk, and 2/3 cup of molasses. Put the water and powdered milk in a container. Stir it unti the water and milk look fully mixed. Add the molasses. Stir again until the mixture appears to have an even color. The patient must be placed on the left side; insert the soft tube at least 12 inches beyond the rectum. Turn the patient on the right side, release the solution, and clamp the enema tube and leave it in place for 20 min while the patient stays on the right side. Then pull the tube out and let the patient evacuate his or her bowels (10)

\section{B. Bowel maintenance program and intervention for grade 1 and 2 constipation:}

1. Set expectations for frequency of bowel movements.

2. The patient needs three daily meals to facilitate normal peristaltic pushdown.

3. Fiber content should be $25-40 \mathrm{~g}$ only if the patient drinks two quarts of fluid/day. Fiber without fluid will constipate.

4. The patients should take a stimulant laxative to increase peristaltic pushdown and stool softener (e.g. docusate + senna (Senna-S)) to hold fluid in the stool to counteract any constipating medications and to compensate for high catecholamine levels from the disease process.

5. Titrate Senna-S up to eight tablets/day, especially during chemotherapy with vinca alkaloids, ondansetron, and/or opiates.

6. If the previous measures do not work, add polyethylene glycol.

7. If no bowel movement occurs on an expected day, the patient should take two tablespoons of mineral oil and two caplets or tow tablespoons of magnesium hydroxide at bedtime.

\section{Figure 1}

Algorithm for the management of constipation. 
of stool that trap gas, and stool softeners alone are ineffective in more advanced constipation. (3) Stimulant laxatives and stool softeners are used for the treatment of grade 1 and 2 constipation or for a maintenance program to offset the effect of constipating medications or symptoms of constipation caused by the disease process.

\section{Statistical analysis}

The study population was defined as the patients in whom the initial presenting symptom was constipation, alone or in combination with other symptoms. The control population was defined as the patients with $\mathrm{PH} / \mathrm{PG}$ whose presenting symptoms did not include constipation.

Analyses were performed using R (version 3.0.2), SAS (version 9.2; SAS Institute Inc., Cary, NC, USA), and SPSS (version 17.0) Software. Descriptive statistics were used to summarize the data. Medians and ranges were computed for continuous variables, given the unequally distributed population in our cohort. For categorical variables, frequencies and percentages were calculated. Fisher's exact test was used for comparisons of two proportions. Paired $t$-test was used for comparisons of before and after treatment effect. Logistic regression was applied to explore the correlation between the symptom of constipation and other prognostic factors, including level of catecholamines.

\section{Results}

\section{Demographics}

Of the 396 included patients with PH/PG, 23 were identified who had constipation as a presenting complaint. Their median age was 46 years (range $=25-71$ ). Nine were women and 14 were men. Table 1 shows the patients' demographic and tumor characteristics. The control population consisted of 373 cases with the median age of 41.1 years (range $=5-78$ ), of which 192 were female and 181 male. The differences between the two groups in median age and sex ratio were not statistically significant when compared by $t$-test and Fisher's exact test, respectively.

\section{Tumor types}

Of the 23 patients presenting with constipation, 15 patients had a single $\mathrm{PH}$, six patients had PG, and

Table 1 Demographic and tumor information for patients with PH/PG who presented with constipation.

\begin{tabular}{|c|c|c|}
\hline Case no. & $\begin{array}{l}\text { Age at } \\
\text { diagnosis } \\
\text { (years) }\end{array}$ & Sex \\
\hline 1 & 54 & $F$ \\
\hline 2 & 37 & $M$ \\
\hline 3 & 26 & $M$ \\
\hline 4 & 61 & $M$ \\
\hline 5 & 37 & $M$ \\
\hline 6 & 34 & $F$ \\
\hline 7 & 25 & $\mathrm{~F}$ \\
\hline 8 & 50 & $\mathrm{~F}$ \\
\hline 9 & 48 & $M$ \\
\hline 10 & 50 & $\mathrm{~F}$ \\
\hline 11 & 38 & $M$ \\
\hline 12 & 34 & $M$ \\
\hline 13 & 57 & $F$ \\
\hline 14 & 71 & $\mathrm{~F}$ \\
\hline 15 & 46 & $F$ \\
\hline 16 & 39 & $F$ \\
\hline 17 & 46 & M \\
\hline 18 & 49 & $M$ \\
\hline 19 & 52 & $M$ \\
\hline 20 & 56 & $M$ \\
\hline 21 & 51 & $\mathrm{M}$ \\
\hline 22 & 40 & $\mathrm{M}$ \\
\hline 23 & 58 & $\mathrm{M}$ \\
\hline
\end{tabular}

\begin{tabular}{c}
\hline Ethnicity \\
\hline W \\
W \\
W \\
W \\
W \\
W \\
W \\
B \\
B \\
W \\
W \\
H \\
W \\
B \\
H \\
W \\
W \\
W \\
W \\
W \\
W \\
W \\
W \\
\end{tabular}

\begin{tabular}{c}
\hline Tumor type \\
\hline $\mathrm{PH}$ \\
$\mathrm{PH}$ \\
$\mathrm{PG}$ \\
$\mathrm{PH}$ \\
$\mathrm{PH} / \mathrm{PG}$ \\
$\mathrm{PH}$ \\
$\mathrm{PG}$ \\
$\mathrm{PH}$ \\
$\mathrm{PH}$ \\
$\mathrm{PH}$ \\
$\mathrm{PH}$ \\
$\mathrm{PG} / \mathrm{PH}$
\end{tabular}

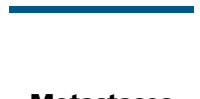

\begin{tabular}{l} 
Primary tumor location \\
\hline Right adrenal \\
Right adrenal \\
Prostate \\
Left adrenal \\
Left adrenal \\
Left adrenal \\
Para-aortic \\
Left adrenal \\
Right adrenal \\
Left adrenal \\
Right adrenal \\
Para-aortic right/left \\
adrenal \\
Left adrenal \\
Retroperitoneal \\
Right adrenal \\
Right/left adrenal \\
Para-aortic \\
Para-aortic \\
Right adrenal \\
Left adrenal \\
Para-aortic \\
Left adrenal \\
Left adrenal \\
\hline
\end{tabular}

\begin{tabular}{c}
$\begin{array}{c}\text { Primary tumor } \\
\text { size }(\mathrm{cm})\end{array}$ \\
\hline 12 \\
16 \\
8 \\
4 \\
8 \\
3.7 \\
4 \\
8 \\
18 \\
3.9 \\
7.2 \\
3.2 \\
7 \\
7.5 \\
13 \\
5.1 \\
4.5 \\
6.5 \\
8.4 \\
6 \\
6 \\
11.5 \\
9 \\
\end{tabular}

F, female; M, male; W, white; B, black; H, Hispanic. 
two patients had multiple PH/PGs. Their median primary tumor size was $6.9 \mathrm{~cm}$, compared to $6.5 \mathrm{~cm}$ in the control group, with no statistical significance between groups. Of the 23 affected patients, ten had non-metastatic disease, while 13 had metastatic tumors: synchronous metastases in seven patients and metachronous metastases in six patients. In comparison, of the control population, 244 patients had nonmetastatic tumors, while 129 patients had malignant disease: synchronous metastases in 61 patients and metachronous metastases in 68 patients. The association between tumor metastatic status and constipation was significant $(P=0.043)$ based on Fisher's exact test; therefore, patients with metastatic disease have an increased likelihood of constipation as an initial presenting complaint.

\section{Biological features/biochemical analyses}

Results of genetic testing were available for 17 of 23 patients with constipation. Of these, two patients had multiple endocrine neoplasia type 2A (MEN2A), two patients had a PG syndrome type 4, one patient had von Hippel-Lindau disease, and one patient had a PG syndrome type 1 . Eleven patients had apparently sporadic disease (negative genetic testing results). These patients were tested for $S D H x$ and $V H L$ mutations exhibiting normal results. Gene testing for fumarate hydratase germline mutations was not available.

We compared the concentrations of fractionated urinary normetanephrines (UNM) and metanephrines (UM) and plasma normetanephrines (PNM) and metanephrines (PM) between patients presenting with and without constipation. Of interest, the sample was heterogeneous, and many patients did not have constipation despite high concentrations of these metabolites. Of the 23 patients with constipation, 21 had a biochemical phenotype predominantly characterized by increased production of noradrenaline. In the other two patients with constipation, no information on biochemical phenotype was available; these two patients had MEN2A. Five of the 23 constipation patients had measurements of UNM, and 16 had measurements of PNM (Table 2). Because UNM, UM, PNM, and PM were measured using different scales and methods among our patients, their levels relative to the upper bound of the normal range were calculated for analysis. Using logistic regression analysis, the odds ratio for association of elevated UNM with constipation was $1.025(P=0.035)$; for PNM, the odds ratio was 1.021
Table 2 Urinary and plasma normetanephrine (UNM and PNM) levels for PH/PG patients who presented with and without constipation.

\begin{tabular}{|c|c|c|c|}
\hline $\begin{array}{l}\text { Normetanephrine } \\
\text { levels }\end{array}$ & $\begin{array}{l}\text { Patients } \\
\text { with } \\
\text { constipation }\end{array}$ & $\begin{array}{l}\text { Control } \\
\text { population }\end{array}$ & $P$ value \\
\hline \multicolumn{4}{|l|}{ Relative UNM concentration } \\
\hline $\begin{array}{l}\text { Number of patients } \\
\text { with data }\end{array}$ & 5 & 86 & \\
\hline Mean concentration (s.D.) & $36.9(70.0)$ & $7.3(14.3)$ & $<0.001$ \\
\hline \multicolumn{4}{|c|}{ Relative PNM concentration } \\
\hline $\begin{array}{l}\text { Number of patients } \\
\text { with data }\end{array}$ & 16 & 83 & \\
\hline Mean concentration (s.D.) & $32.0(38.1)$ & $13.6(22.5)$ & $<0.001$ \\
\hline \multicolumn{4}{|c|}{ Number of patients with level } \\
\hline $\begin{array}{l}\leq 30 \text { times upper bound } \\
\text { of normal range }\end{array}$ & 10 & 73 & \\
\hline $\begin{array}{l}>30 \text { times upper bound } \\
\text { of normal range }\end{array}$ & 6 & 10 & \\
\hline
\end{tabular}

$(P=0.018)$. Thus, increased concentrations of UNM and PNM were associated with constipation, and a patient with UNM or PNM concentrations ten times higher than normal was $\sim 25 \%$ more likely to have constipation. No association was found between UM or PM and constipation status. Of the 99 patients for whom we had PNM data, 16 patients presented with constipation, and 6 (37.5\%) of the 16 had PNM values at least 30 times as high as the normal upper bound. In comparison, among the 83 patients with PNM data who did not present with constipation, 10 (12\%) had PNM values at least 30 times as high as the normal upper bound. The odds ratio for association with constipation for a PNM cutoff of 30 times the normal upper bound was $4.38(P=0.017)$, suggesting that patients with tumors that produce very high amounts of catecholamines, mainly noradrenaline are at a higher risk for this complication.

Of interest, none of the patients with normal NM and $\mathrm{M}(n=89)$ had constipation at initial presentation $(P<0.001)$.

\section{Clinical features}

The classic triad of PH/PG presenting symptoms palpitations, headaches, and diaphoresis - was noted in $35 \%$ of the affected group $(n=23)$, compared to $6 \%$ of the control group $(n=373)(P<0.001)$. Patients with constipation $(n=23)$ were more likely than the control group $(n=373)$ to present with weight loss $(P<0.001)$. None of the patients with constipation exhibited hypercalcemia. 


\section{Severity of constipation}

At the time of presentation at MD Anderson, eight patients (34.8\%) had grade 1 constipation; seven patients (30\%), grade 2 ; one patient (4.3\%), grade 3 ; and five patients $(21.8 \%)$, grade 4 . Two patients $(8.7 \%)$ died because of constipation (i.e., grade 5). The duration of constipation prior to presentation were: for patients with grade 1 , median of 1.9 months ( $0.5-3.5$ months); grade 2 , median of 3.8 months (2.2-5 months); grade 3, 6 months (single patient); grade 4 , median of 9 months (8.3-13 months); and grade 5, median of 15 months (12 and 18 months) (Table 3). Patients with grade 4 constipation complained of nausea and vomiting, were dehydrated, exhibited elevated creatinine and BUN levels, had difficulty controlling hypertension, and frequently experienced fever. In the patients with grade 5 constipation, toxic megacolon and septicemia, despite antibiotic therapy, were the causes of death.

Other complications associated with constipation included urinary tract infection (one patient), rectal bleeding and stercoral ulcers (one patient), and hemorrhoids (three patients).

\section{Medications at initial presentation}

Treatment approaches when the patients presented at our institution differed among the patients. All patients with constipation were receiving $\alpha$ - and $\beta$-blockers. The 15 patients with grade 1 and 2 constipation were receiving an average of 2.3 antihypertensive medications each. Only three of these patients were taking laxatives.

The eight patients who presented with grade 3-5 constipation were treated with an average of 4.5 antihypertensive medications. In addition to receiving $\alpha$ - and $\beta$-blockers, these patients were treated with ACE inhibitors, calcium channel blockers, hydralazine, tyrosine hydroxylase inhibitors, and/or clonidine. Six patients were taking at least one laxative. Two patients were not taking any laxatives. All patients with grade 4 and 5 constipation (30\% of the cohort with constipation) were admitted to the hospital. Table 3 shows the medications given to the patients with constipation.

\section{Treatment provided after initial assessment at MD Anderson}

Grade 1 and 2 constipation - All patients with grade 1 and 2 constipation were treated with a diet enriched with fiber ( $\geq 24 \mathrm{~g}$ ), abundant liquids ( $\geq 2$ quarts of liquids daily), a stimulant laxative, and a stool softener, as described in Fig. 1B. All these patients reported an increased frequency (1-2 daily bowel movements) and softness of bowel movements. Ten of these patients underwent resection of non-metastatic PH/PG. Their constipation resolved after surgery.

Grade 3 and 4 constipation $>$ The six patients with grade 3 and 4 constipation were treated with the Bisanz algorithm presented in Fig. 1A. All these patients reported an average of six daily bowel movements that occurred over a period no longer than $72 \mathrm{~h}$ after initiation of treatment. An example of the imaging findings of these patients is presented in Fig. 2. After treatment, all patients reported quality-of-life improvement (better appetite and less abdominal pain and abdominal distention); the patients with grade 4 constipation exhibited increment of the glomerular filtration rate $(P=0.0473)$ and had lower blood pressure $(P=0.0031)$ and pulse $(P=0.0021)$, decreased white blood cells $(P=0.0092)$, and lower temperature $(P=0.0075) 72 \mathrm{~h}$ after admission (Fig. 3).

Four patients continued treatment with a maintenance regimen characterized by a diet enriched with fiber, abundant water, laxative stimulants, and stool softener, as described in Fig. 2B. One patient underwent resection of the tumor. She is currently alive without constipation and no evidence of $\mathrm{PH}$. The other three patients had progressive metastatic $\mathrm{PH} / \mathrm{PG}$ that required chemotherapy with CVD combined with ondansetron and opiates for painful metastases. The patients continued a diet enriched with fiber, water, and docusate/senna (Senna-S), up to eight tablets daily, and did not experience constipation, even while on chemotherapy. The other two patients with grade 4 constipation did not continue on the maintenance therapy program owing to transfer to another facility at the request of their insurance companies, and their treatment for constipation was stopped. Both patients eventually required an ileostomy. One patient has been alive with stable disease for 2 years and no constipation. The other patient died because of disease progression; the patient did not have constipation at the time of death.

\section{Discussion}

Our observations indicate that constipation is a complication observed in occasional PH/PG patients, usually with primary tumors larger than $5 \mathrm{~cm}$ or with extensive metastatic disease. These tumors were shown to secrete excessive amounts of catecholamines, mainly 
Table 3 Severity and duration of constipation and medications at initial presentation for patients who presented with constipation.

\begin{tabular}{|c|c|c|c|c|}
\hline $\begin{array}{l}\text { Case } \\
\text { no. }\end{array}$ & $\begin{array}{l}\text { Grade } \\
\text { of } \\
\text { consti- } \\
\text { pation }\end{array}$ & $\begin{array}{l}\text { Duration } \\
\text { prior to } \\
\text { presen- } \\
\text { tation } \\
\text { (months) }\end{array}$ & $\begin{array}{l}\text { Anti-hypertensive } \\
\text { drugs }\end{array}$ & Laxatives \\
\hline 1 & 3 & 6 & $\begin{array}{l}\text { Phenoxybenzamine } \\
\quad 60 \mathrm{mg} \\
\text { Propranolol } 60 \mathrm{mg} \\
\text { Lisinopril } 20 \mathrm{mg}\end{array}$ & Senna \\
\hline 2 & 1 & 1 & $\begin{array}{l}\text { Phenoxybenzamine } \\
\quad 40 \mathrm{mg} \\
\text { Propranolol } 100 \mathrm{mg}\end{array}$ & None \\
\hline 3 & 4 & 8.7 & $\begin{array}{l}\text { Phenoxybenzamine } \\
50 \mathrm{mg} \\
\text { Propranolol } 80 \mathrm{mg} \\
\text { Lisinopril } 40 \mathrm{mg}\end{array}$ & Bisacodyl \\
\hline 4 & $2^{a}$ & 3.8 & $\begin{array}{l}\text { Phenoxybenzamine } \\
\quad 60 \mathrm{mg} \\
\text { Propranolol } 80 \mathrm{mg}\end{array}$ & None \\
\hline 5 & $1^{\mathrm{a}}$ & 3.5 & $\begin{array}{l}\text { Phenoxybenzamine } \\
20 \mathrm{mg} \\
\text { Propranolol } 80 \mathrm{mg}\end{array}$ & None \\
\hline 6 & $1^{\mathrm{a}}$ & 0.5 & $\begin{array}{l}\text { Phenoxybenzamine } \\
10 \mathrm{mg} \\
\text { Atenolol } 25 \mathrm{mg}\end{array}$ & None \\
\hline 7 & $1^{\mathrm{a}}$ & 1.8 & $\begin{array}{l}\text { Phenoxybenzamine } \\
10 \mathrm{mg} \\
\text { Propranolol } 60 \mathrm{mg}\end{array}$ & None \\
\hline 8 & $2^{a}$ & 3.8 & $\begin{array}{l}\text { Phenoxybenzamine } \\
20 \mathrm{mg} \\
\text { Propranolol } 40 \mathrm{mg}\end{array}$ & None \\
\hline 9 & 2 & 5 & $\begin{array}{l}\text { Doxazosin } 16 \mathrm{mg} \\
\text { Amlodipine } 10 \mathrm{mg} \\
\text { Propranolol } 60 \mathrm{mg} \\
\text { Clonidine } 0.6 \mathrm{mg} \\
\text { Hydralazine } 150 \mathrm{mg} \\
\text { Hydrochlorothiazide } \\
25 \mathrm{mg}\end{array}$ & None \\
\hline 10 & $1^{\mathrm{a}}$ & 1.3 & $\begin{array}{l}\text { Phenoxybenzamine } \\
20 \mathrm{mg} \\
\text { Propranolol } 40 \mathrm{mg}\end{array}$ & None \\
\hline 11 & $1^{\mathrm{a}}$ & 2 & None & None \\
\hline 12 & $1^{\mathrm{a}}$ & 2.4 & $\begin{array}{l}\text { Phenoxybenzamine } \\
20 \mathrm{mg} \\
\text { Propranolol } 40 \mathrm{mg}\end{array}$ & None \\
\hline 13 & 4 & 9 & $\begin{array}{l}\text { Phenoxybenzamine } \\
\quad 30 \mathrm{mg} \\
\text { Labetalol } 400 \mathrm{mg} \\
\text { Nicardapine } 20 \mathrm{mg} \\
\text { Metyrosine } 1000 \mathrm{mg} \\
\text { Clonidine } 0.2 \mathrm{mg}\end{array}$ & None \\
\hline
\end{tabular}

noradrenaline, and based on our statistical analysis, we believe that these hormones are responsible for this complication. Three different clinical observations also support this finding: i) Chronic constipation was not noticed in patients with $\mathrm{PH} / \mathrm{PGs}$ that did not secrete adrenaline and/or noradrenaline. ii) In patients with hormonally active disease, this symptom improved after resection of the tumor. iii) Constipation is frequently associated with the classic triad of palpitations, headaches,
Table 3 Continued.

\begin{tabular}{|c|c|c|c|c|}
\hline $\begin{array}{l}\text { Case } \\
\text { no. }\end{array}$ & $\begin{array}{l}\text { Grade } \\
\text { of } \\
\text { consti- } \\
\text { pation }\end{array}$ & $\begin{array}{l}\text { Duration } \\
\text { prior to } \\
\text { presen- } \\
\text { tation } \\
\text { (months) }\end{array}$ & $\begin{array}{l}\text { Anti-hypertensive } \\
\text { drugs }\end{array}$ & Laxatives \\
\hline 14 & $1^{a}$ & 3 & $\begin{array}{l}\text { Amlodipine } 10 \mathrm{mg} \\
\text { Atenolol } 100 \mathrm{mg}\end{array}$ & None \\
\hline 15 & $4^{a}$ & 11 & $\begin{array}{l}\text { Metoprolol } 100 \mathrm{mg} \\
\text { Doxazosin } 16 \mathrm{mg} \\
\text { Lisinopril } 40 \mathrm{mg} \\
\text { Labetalol } 400 \mathrm{mg} \\
\text { Clonidine } 0.1 \mathrm{mg} \\
\text { Phentolamine } \\
\quad 2 \mathrm{mg} / \mathrm{min}\end{array}$ & None \\
\hline 16 & $2^{a}$ & 5 & $\begin{array}{l}\text { Phenoxybenzamine } \\
120 \mathrm{mg} \\
\text { Propranolol } 90 \mathrm{mg} \\
\text { Metyrosine } 1000 \mathrm{mg}\end{array}$ & $\begin{array}{l}\text { Dried plum } \\
\text { Senna }\end{array}$ \\
\hline 17 & $4^{b}$ & 8.3 & $\begin{array}{l}\text { Phenoxybenzamine } \\
\quad 40 \mathrm{mg} \\
\text { Propranolol } 60 \mathrm{mg} \\
\text { Enalapril } 20 \mathrm{mg} \text { daily } \\
\text { Amlodipine } 10 \mathrm{mg} \\
\text { daily } \\
\text { Carvedilol } 37.5 \mathrm{mg} \\
\text { daily }\end{array}$ & $\begin{array}{l}\text { Polyethylene } \\
\text { glycol }\end{array}$ \\
\hline 18 & $4^{b}$ & 13 & $\begin{array}{l}\text { Phenoxybenzamine } \\
\quad 60 \mathrm{mg} \\
\text { Metyrosine } 750 \mathrm{mg} \\
\text { Ramipril } 5 \mathrm{mg} \\
\text { Carvedilol } 50 \mathrm{mg} \\
\text { Diltiazem } \\
\text { Hydrochlorothiazide } \\
12.5 \mathrm{mg}\end{array}$ & $\begin{array}{l}\text { Docusate } \\
\text { Polyethylene } \\
\text { glycol }\end{array}$ \\
\hline 19 & 2 & 4.5 & $\begin{array}{l}\text { Phenoxybenzamine } \\
20 \mathrm{mg} \\
\text { Metoprolol } 200 \mathrm{mg}\end{array}$ & $\begin{array}{l}\text { Polyethylene } \\
\text { glycol }\end{array}$ \\
\hline 20 & 5 & 18 & $\begin{array}{l}\text { Phenoxybenzamine } \\
100 \mathrm{mg} \\
\text { Atenolol } 100 \mathrm{mg} \\
\text { Amlodipine } 5 \mathrm{mg} \\
\text { Clonidine } 0.6 \mathrm{mg}\end{array}$ & None \\
\hline 21 & 5 & 12 & $\begin{array}{l}\text { Doxazosin } 8 \mathrm{mg} \\
\text { Propranolol } 60 \mathrm{mg} \\
\text { Phenoxybenzamine } \\
\quad 60 \mathrm{mg}\end{array}$ & Docusate \\
\hline 22 & 2 & 2 & $\begin{array}{l}\text { Doxazosin } 8 \mathrm{mg} \\
\text { Metoprolol } 50 \mathrm{mg}\end{array}$ & None \\
\hline 23 & 2 & 2.1 & $\begin{array}{l}\text { Labetalol } 400 \mathrm{mg} \\
\text { Doxazosin } 4 \mathrm{mg}\end{array}$ & Senna \\
\hline
\end{tabular}

${ }^{a}$ Constipation ended after surgery of the primary tumor.

${ }^{b}$ Constipation ended after lleostomy at another institution.

and diaphoresis, which are symptoms of adrenergic toxicity. There are, however, a substantial number of patients with $\mathrm{PH} / \mathrm{PGs}$ that secrete excessive amounts of noradrenaline/adrenaline who do not complain of constipation and in whom the symptoms of adrenergic toxicity are more subtle. It is unclear why these patients do not develop constipation or more dramatic hormonal manifestations; post-receptor downregulatory mechanisms may explain these phenomena $(13,14)$. 


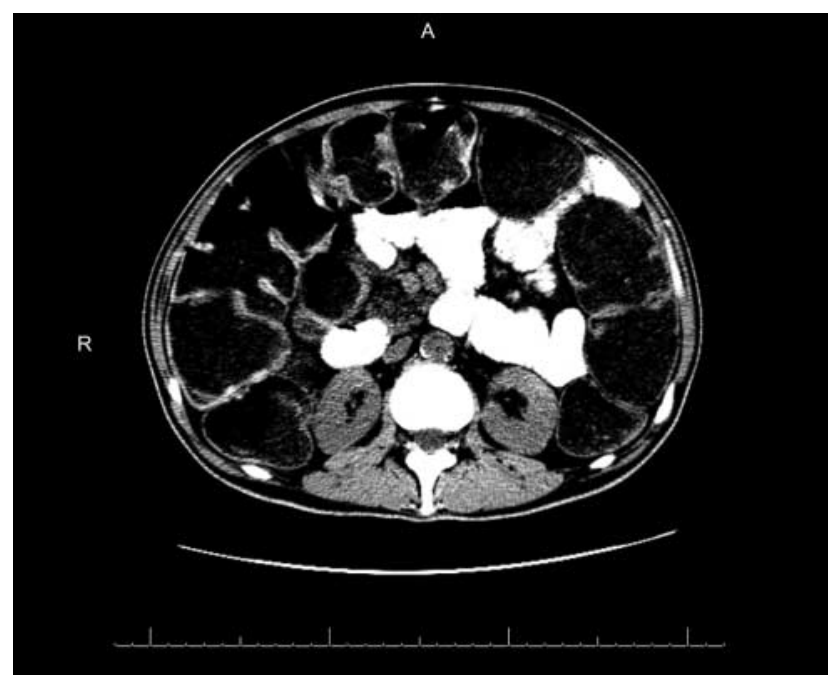

\section{Figure 2}

Constipation. The colon of this individual with a malignant noradrenaline-secreting sympathetic paraganglioma is dilated and full of stool.

The smooth muscle of the gastrointestinal tract contains $\alpha-1, \alpha-2$, and $\beta-2$ adrenergic receptors. These receptors bind adrenaline and noradrenaline. Binding activates G-protein-dependent pathways that activate adenylate cyclase conversion of ATP to cAMP. cAMP regulates the activity of protein kinase $A$, an important regulator of downstream activity. $\alpha-1$ and -2 receptors have a higher selective affinity for noradrenaline and adrenaline, respectively, resulting in splanchnic vascular smooth muscle contraction and contraction of pyloric and ileocecal sphincters; meanwhile, stimulation of $\beta-2$ receptors by their primary ligand, adrenaline, results in intestinal smooth muscle relaxation $(15,16,17)$.

Pharmacologic studies in dogs and rabbits show that extremely high levels of adrenaline/noradrenaline relax intestinal smooth muscle and result in colonic dilatation and bleeding (18). With persistent catecholamine excess, a vicious cycle of tonic vasoconstriction of intestinal blood supply and decreased intestinal motility may be perpetuated. Constriction of the splanchnic blood supply may lead to bowel wall ischemia, which further contributes to decreased motility and constipation. In addition, owing to chronic hypertension, fibrinoid necrosis of intramural arterioles may lead to a further reduction in vascular supply. In this setting, fecal material can be retained in the gastrointestinal tract, and progressive reabsorption of water can result in dry, hard stools that get attached to the mucosa, predisposing to pressure necrosis, stercoral colitis and ulceration, bleeding, and perforation (19). In addition, patients can have obstruction and develop megacolon after holding stool for long periods of time (20).

Abdominal series and CT scans are recommended for patients with grade 3 and 4 constipation to quantify the amount of stool and identify patients at risk for severe complications or death (e.g., patients with fat stranding, mucosal sloughing, mesenteric hyperemia, or extraluminal gas) $(19,20)$.

Our results also indicate that the longer the duration of constipation, the more difficult its management because of related complications. Unfortunately, this symptom had rarely been addressed in most of our patients before presenting to our institution. Thus, we suspect that the true prevalence of constipation may be underestimated because of multiple factors, which include misunderstanding on the patient's part as to what defines constipation and the fact that physicians often overlook the seriousness of this condition as they focus on controlling the tumor burden and other adrenergic symptoms such as hypertension $(21,22)$. In fact, at the time of initial assessment at MD Anderson, our patients had previously been treated with $\alpha$ - and $\beta$-blockers, but rarely with diet, fiber, fluids, and laxatives.

It is not surprising that a substantial number of patients with constipation exhibit weight loss. Although this symptom may be explained in part by increased catabolism induced by catecholamines and in some patients by the presence of malignancy, the intestinal fullness due to constipation likely plays a major role in the development of anorexia. Lack of daily dietary intake further perpetuates the constipation (10).

This study provides a systematic description on how to treat constipation in patients with $\mathrm{PH} / \mathrm{PG}$. The competitive and noncompetitive $\alpha$ - and $\beta$-blockers, despite antagonizing noradrenaline and adrenaline, do not seem effective in controlling the toxicity of catecholamines in the gastrointestinal tract. In fact, our patients with grade 3-5 constipation had been treated with high doses of these drugs. Although one of the side effects of metyrosine, an anti-catecholamine, is diarrhea (23), this medication was not effective in improving constipation, although the doses given were limited to $1000 \mathrm{mg}$ or lower because of the drug's side effects (e.g., anxiety, depression, hallucinations, and fatigue).

Conversely, constipation was acutely relieved in patients with moderate to severe constipation by a combination of interventions through the upper and lower gastrointestinal tract that included a diet enriched with fiber, two quarts or more of water, oral and rectal lubricants, oral osmotic laxatives, and small-volume 
(A)

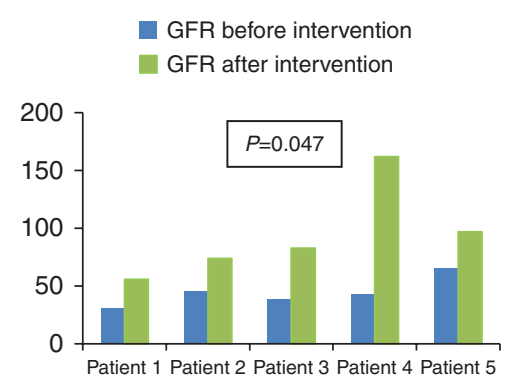

(B)

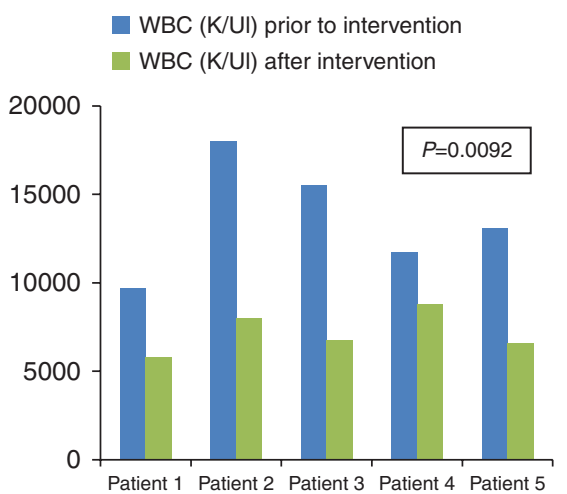

(C) Temperature prior to intervention (Celsius)

- Temperature after intervention (Celsius)

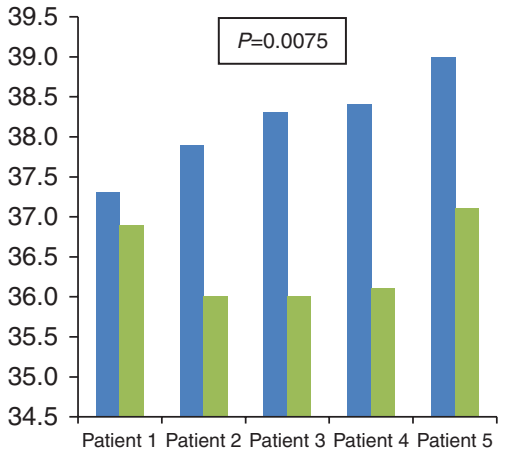

(D)

Pulse rate prior to intervention (beats/minute)

- Pulse rate after intervention (beats/minute)

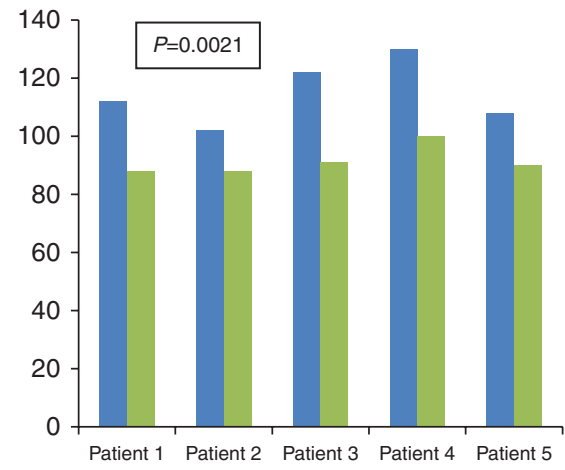

(E)

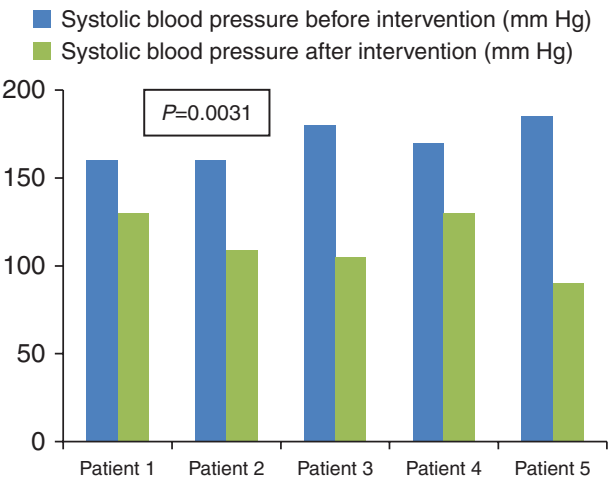

\section{Figure 3}

Clinical and biochemical characteristics of patients with grade 4 constipation before and $72 \mathrm{~h}$ after intervention: (A) GFR; (B) WBC; (C) Temperature; (D) Pulse; (E) systolic blood pressure.

hypertonic enemas (11). Improving constipation in these patients allowed better blood pressure, pulse, and kidney function. Because many $\mathrm{PH} / \mathrm{PG}$ patients have unresectable metastatic tumors or need aggressive hypertension management prior to surgery, a maintenance regimen that combines a diet enriched with fiber, water, stool softeners, and stimulants is required to prevent recurrent constipation. As the high catecholamine levels decrease peristalsis, with subsequent increased reabsorption of water from the colon, a combination of stimulant laxative and stool softener antagonizes these effects by increasing peristalsis and retaining fluid in the colon. $\alpha$ - and $\beta$-blockers do not increase peristalsis (24).

In our experience, all patients with grade 1 and 2 constipation treated with a diet enriched with fiber and gastrointestinal stimulants and stool softeners had improvement in their constipation. Because more severe forms of constipation start mildly, this finding suggests that severe constipation may be preventable. Patients with metastatic PH/PG may be at a higher risk for constipation as they are frequently treated with vincristine-based chemotherapy, antiemetics such as ondansetron, and/or narcotics to relieve pain $(25,26)$, all of which have constipating effects. In these patients, early intervention with medications that offset the constipating effects and close evaluation of this symptom are required. In $\mathrm{PH} / \mathrm{PG}$ patients receiving narcotics, methylnaltrexone bromide (a $\mu$ antagonist) could be an effective treatment to offset opiate-induced constipation that is refractory to laxative therapy (27). So far, we do not have experience with this drug in this patient population.

Based on our experience and different from other reports, if constipation is managed from the time the diagnosis is made, ileostomy is not required to control the constipation. Patients with megacolon may respond to a bowel-training program. Bowel training involves emptying the colon every day at the same time with the stimulus of prune juice, a big meal, and a hot liquid, followed by a 
bisacodyl suppository (10). This program gradually decreases the size of the colon to normal size; it then can respond to normal maintenance therapy as described above. A colostomy is not recommended as patients can still get constipated with the colostomy $(28,29)$.

Differential diagnosis of constipation in patients with PH/PG includes intestinal pseudo-obstruction (3); the latter is characterized by air in the gastrointestinal tract due to decreased intestinal motility. Abdominal series help differentiate this condition from constipation. Pseudo-obstruction may be associated with death due to progressive distention and subsequent rupture of the cecum (usually with a cecal diameter larger than $12 \mathrm{~cm}$ ) (30). It is important to differentiate the two conditions because their treatments differ. Patients with pseudoobstruction may need endoscopic suction, rectal tubes, positional changes, and sometimes neostigmine.

In summary, constipation is a rare complication observed in patients with usually large, catecholaminesecreting $\mathrm{PH} / \mathrm{PGs}$. Most patients present with mild to moderate constipation, occasionally with severe constipation. Severe constipation may lead to death if not managed. The treatment of constipation includes a diet rich in fiber, liquids, laxatives, and eliminating the source of catecholamines by tumor resection if possible. Severe constipation is preventable.

\section{Declaration of interest}

The authors declare that there is no conflict of interest that could be perceived as prejudicing the impartiality of the research reported.

\section{Funding}

Financial support has been provided by a grant from the Team NAT Foundation for the understanding and treatment of patients with malignant pheochromocytomas and paragangliomas.

\section{Author contribution statement}

Study concept and design-1; acquisition of data-2; analysis and interpretation of data-3; drafting of the manuscript-4; critical revision of the manuscript for important intellectual content-5; statistical analysis-6; obtained funding-7; administrative, technical, or material support-8; study supervision-9. S Thosani 1,2,3,4,5,6,9; M Ayala-Ramirez 1,2,3,4,5,6,7; A Roman-Gonzalez 1,3,4,5,6,8; S Zhou 1,2,3,4,5,6; N Thosani 1,3,4,5,6; A Bisanz 1,2,3,4,5,8,9; C Jimenez 1,2,3,4,5,6,7,8,9.

\section{References}

1 Osinga TE, Kerstens MN, van der Klauw MM, Koornstra JJ, Wolffenbuttel BH, Links TP \& van der Horst-Schrivers AN. Intestinal pseudo-obstruction as a complication of paragangliomas: case report and literature review. Netherlands Journal of Medicine $2013 \mathbf{7 1}$ 512-517.

2 Huang WS, Wang CS, Hsieh CC, Lin PY, Chin CC \& Wang JY. Management of patients with stercoral perforation of the sigmoid colon: report of five cases. World Journal of Gastroenterology 200612 500-503.

3 Karri V, Khan SL \& Wilson Y. Bowel perforation as a presenting feature of pheochromocytoma: case report and literature review. Endocrine Practice 200511 385-388. (doi:10.4158/EP.11.6.385)

4 Thurtle OA, Allen AP, Walters MT, Kitchen JV, Smith CL \& Cawley MI. Intractable constipation in malignant phaeochromocytoma: combined treatment with adrenergic blockade and cholinergic drugs. Journal of the Royal Society of Medicine 198477 327-328.

5 Hashimoto Y, Motoyoshi S, Maruyama H, Sakakida M, Yano T, Yamaguchi K, Goto K, Sugihara S, Takano S \& Kambara T. The treatment of pheochromocytoma associated with pseudo-obstruction and perforation of the colon, hepatic failure, and DIC.

Japanese Journal of Medicine 199029 341-346. (doi:10.2169/internalmedicine1962.29.341)

6 Bharucha AE, Dorn SD, Lembo A, Pressman A \& American Gastroenterological Association. American Gastroenterological Association medical position statement on constipation. Gastroenterology 2013144 211-217. (doi:10.1053/j.gastro.2012.10.029)

7 Cleeland CS, Mendoza TR, Wang XS, Chou C, Harle MT, Morrissey M \& Engstrom MC. Assessing symptom distress in cancer patients: the M.D. Anderson Symptom Inventory. Cancer 200089 1634-1646. (doi:10. 1002/1097-0142(20001001)89:7<1634::AID-CNCR29>3.0.CO;2-V)

8 Talley NJ, Lasch KL \& Baum CL. A gap in our understanding: chronic constipation and its comorbid conditions. Clinical Gastroenterology and Hepatology 20097 9-19. (doi:10.1016/j.cgh.2008.07.005)

9 Avila JG. Pharmacologic treatment of constipation in cancer patients. Cancer Control 200411 10-18.

10 Woolery M, Bisanz A, Lyons HF, Gaido L, Yenulevich M, Fulton S \& McMillan SC. Putting evidence into practice: evidence-based interventions for the prevention and management of constipation in patients with cancer. Clinical Journal of Oncology Nursing 200812 317-337. (doi:10.1188/08.CJON.317-337)

11 Bisanz A. Managing bowel elimination problems in patients with cancer. Oncology Nursing Forum 199724 679-686; quiz 687-678.

12 Twycross R, Sykes N, Mihalyo M \& Wilcock A. Stimulant laxatives and opioid-induced constipation. Journal of Pain and Symptom Management 201243 306-313. (doi:10.1016/j.jpainsymman.2011.12.002)

13 Shukla AK, Westfield GH, Xiao K, Reis RI, Huang LY, Tripathi-Shukla P, Qian J, Li S, Blanc A, Oleskie AN et al. Visualization of arrestin recruitment by a G-protein-coupled receptor. Nature 2014512 218-222. (doi:10.1038/nature13430)

14 Rockman HA, Koch WJ \& Lefkowitz RJ. Seven-transmembranespanning receptors and heart function. Nature 2002415 206-212. (doi:10.1038/415206a)

15 Lundgren $\mathrm{O}$, Svanvik J \& Jivegård L. Enteric nervous system. I. Physiology and pathophysiology of the intestinal tract. Digestive Diseases and Sciences 198934 264-283. (doi:10.1007/BF01536062)

16 Goyal RK \& Hirano I. The enteric nervous system. New England Journal of Medicine 1996334 1106-1115. (doi:10.1056/NEJM199604253341707)

17 Liddle R. Gastrointestinal hormones and neurotransmitters. In Sleisenger and Fordtran's Gastrointestinal and Liver Disease Pathophisiology, Diagnosis, Management. pp 3-25. Eds M Feldman \& L Friedman, L Brandt: Saunders Elsevier, 2010.

18 Szakacs JE \& Cannon A. L-Norepinephrine myocarditis. American Journal of Clinical Pathology 195830 425-434.

19 Hussain ZH, Whitehead DA \& Lacy BE. Fecal impaction. Current Gastroenterology Reports 201416 404. (doi:10.1007/s11894-014-0404-2)

20 Saksonov M, Bachar GN, Morgenstern S, Zeina AR, Vasserman M, Protnoy O \& Benjaminov O. Stercoral colitis: a lethal disease-computed tomographic findings and clinical characteristic. Journal of Computer Assisted Tomography 201438 721-726. (doi:10.1097/RCT. 0000000000000117) 
21 Melicow MM. One hundred cases of pheochromocytoma (107 tumors) at the Columbia-Presbyterian Medical Center, 1926-1976: a clinicopathological analysis. Cancer 197740 1987-2004. (doi:10.1002/10970142(197711)40:5 < 1987::AID-CNCR2820400502> 3.0.CO;2-R)

22 Mullen JP, Cartwright RC, Tisherman SE, Misage JR \& Shapiro AP. Pathogenesis and pharmacologic management of pseudo-obstruction of the bowel in pheochromocytoma. American Journal of the Medical Sciences 1985290 155-158. (doi:10.1097/00000441-198510000-00004)

23 Engelman K, Horwitz D, Jéquier E \& Sjoerdsma A. Biochemical and pharmacologic effects of $\alpha$-methyltyrosine in man. Journal of Clinical Investigation 196847 577-594. (doi:10.1172/JCI105754)

24 Robertson D \& Biaggioni I. Adrenoreceptor antagonist drugs. In Basic and Clinical Pharmacology. pp 151-168. Eds B Katzung \& A Trevor. USA: McGraw-Hill Education, 2014.

25 Jimenez C, Rohren E, Habra MA, Rich T, Jimenez P, Ayala-Ramirez M \& Baudin E. Current and future treatments for malignant pheochromocytoma and sympathetic paraganglioma. Current Oncology Reports 2013 15 356-371. (doi:10.1007/s11912-013-0320-x)
26 Baudin E, Habra MA, Deschamps F, Cote G, Dumont F, Cabanillas M, Arfi-Roufe J, Berdelou A, Moon B, Al Ghuzlan A et al. Therapy of endocrine disease: treatment of malignant pheochromocytoma and paraganglioma. European Journal of Endocrinology 2014171 R111-R122. (doi:10.1530/EJE-14-0113)

27 Thomas J, Karver S, Cooney GA, Chamberlain BH, Watt CK, Slatkin NE, Stambler N, Kremer AB \& Israel RJ. Methylnaltrexone for opioidinduced constipation in advanced illness. New England Journal of Medicine 2008358 2332-2343. (doi:10.1056/NEJMoa0707377)

28 Noguera A, Centeno C, Librada S \& Nabal M. Screening for constipation in palliative care patients. Journal of Palliative Medicine 200912 915-920. (doi:10.1089/jpm.2009.0054)

29 Kim YW, Kwon HJ \& Kim IY. Stercoral perforation of the colon in sigmoid colostomy patients: two case reports. International Journal of Surgery Case Reports 20134 1038-1040. (doi:10.1016/j.ijscr. 2013.09.005)

30 De Giorgio R \& Knowles CH. Acute colonic pseudo-obstruction. British Journal of Surgery 200996 229-239. (doi:10.1002/bjs.6480)

Received 4 May 2015

Revised version received 4 June 2015

Accepted 9 June 2015 